\title{
Treatment efficiency of effluent prawn culture by wetland with floating aquatic macrophytes arranged in series
}

\author{
Henares, MNP., ${ }^{a, b *}$ and Camargo, AFM..$^{b, c}$ \\ ${ }^{a}$ Centro Universitário da Fundação Educacional de Barretos - UNIFEB, Avenida Professor Roberto Frade Monte, 389 , \\ CEP 14783-226, Barretos, SP, Brazil

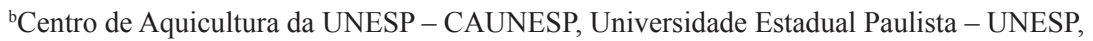 \\ Via de Acesso Paulo Donato Castellane, s/n, CEP 14884-900, Jaboticabal, SP, Brazil \\ 'Departamento de Ecologia, Universidade Estadual Paulista - UNESP, Campus de Rio Claro, \\ Avenida 24-A, 1515, CEP 13506-900, Rio Claro, SP, Brazil \\ *e-mail: henaresmnp@gmail.com
}

Received: June 18, 2013 - Accepted: July 29, 2013

(With 2 figures)

\begin{abstract}
The efficiency of a series of wetland colonized with Eichhornia crassipes and Salvinia molesta to treat the effluent of a giant river prawn (Macrobrachium rosenbergii) broodstock pond was evaluated in this study. The experimental design was completely randomized and was performed in 9 rectangular tanks $\left(1.6 \mathrm{~m}^{3}\right)$ with three treatments (constructed wetlands) and three replicates. The treatment types included: a wetland colonized with E. crassipes and $S$. molesta (EcSm) arranged sequentially, a wetland with E. crassipes only (Ec) and a wetland with $S$. molesta only (Sm). The means of suspended particulate material (SPM), total inorganic nitrogen (TIN), total Kjeldahl nitrogen (TKN), P-orthophosphate $\left(\mathrm{PO}_{4}-\mathrm{P}\right)$ and total phosphorus $(\mathrm{TP})$ of the treated effluents were compared using ANOVA followed by Tukey's test $(P<0.05)$. The effluent treated in Ec and EcSm wetlands exhibited lower SPM concentrations. The Ec wetland reduced TIN, TKN, $\mathrm{PO}_{4}-\mathrm{P}$ and TP by 46.0, 43.7, 44.4 and 43.6\%, respectively. In the EcSm wetland, the reduction of TIN (23.0\%), TKN (33.7\%) and $\mathrm{PO}_{4}-\mathrm{P}(26.7 \%)$ was similar to the Sm wetland (19.8\% TIN, 30.9\% TKN and $\left.23.8 \% \mathrm{PO}_{4}-\mathrm{P}\right)$. The Ec wetland was more efficient in treating pond effluent due likely to the higher root surface of E. crassipes, which forms an extensive area favorable to retention and adsorption of debris and absorption of nutrients.
\end{abstract}

Keywords: constructed wetland, Eichhornia crassipes, Macrobrachium rosenbergii, Salvinia molesta.

\section{Eficiência de wetland com macrófitas aquáticas flutuantes dispostas em serie para o tratamento do efluente do cultivo de camarão}

\begin{abstract}
Resumo
Neste estudo foi avaliada a eficiência de uma wetland povoada com Eichhornia crassipes e Salvinia molesta para o tratamento do efluente de um viveiro de manutenção de reprodutores do camarão-da-malásia (Macrobrachium rosenbergii). Um experimento totalmente casualizado foi realizado em 9 tanques retangulares $\left(1,6 \mathrm{~m}^{3}\right)$ com 3 tratamentos (wetlands construídas) e 3 repetições. Os tratamentos foram: wetland povoada com E. crassipes e S. molesta (EcSm) dispostas nesta sequência, wetland somente com E. crassipes $(\mathrm{Ec})$ e wetland somente com $S$. molesta $(\mathrm{Sm})$. Os valores de material particulado em suspensão (MPS), nitrogênio inorgânico total (NIT), nitrogênio Kjeldahl total (NKT), P-ortofosfato $\left(\mathrm{P}_{-} \mathrm{PO}_{4}\right)$ e fósforo total (PT) dos efluentes tratados foram comparados pela ANOVA seguida do teste de Tukey $(P<0,05)$. A wetland Ec reduziu a concentração de NIT, NKT, P-PO e PT em 46,0\%, 43,7\%, 44,4\% e 43,6\%. $\mathrm{Na}$ wetland EcSm a redução de NIT $(23,0 \%)$, NKT $(33,7 \%)$ e $\mathrm{P}^{-\mathrm{PO}_{4}}(26,7 \%)$ foi semelhante à observada na wetland Sm (19,8\% para NIT, 30,9\% para NKT e 23,8\% para $\left.\mathrm{P}_{-} \mathrm{PO}_{4}\right)$. A wetland povoada com E. crassipes é mais eficiente no tratamento do efluente do viveiro, provavelmente devido a maior superfície radicular da macrófita que permite a formação de uma extensa área propícia à retenção e adsorção dos detritos e à absorção dos nutrientes.
\end{abstract}

Palavras-chave: wetland construída, Eichhornia crassipes, Macrobrachium rosenbergii, Salvinia molesta.

\section{Introduction}

Aquaculture is a very important activity of the worldwide economy. In the last decade, the production of aquatic organisms grew by $47 \%$, reaching approximately 79 million tons in 2010 (FAO, 2012). The increasing demand for aquatic animal products has led world aquaculture to intensify production systems and diversify cultured species. 
Freshwater prawn culture contributes to the expansion of world aquaculture. The world production of the giant river prawn (Macrobrachium rosenbergii De Man, 1879) increased from 82 thousand tons in 1998 to approximately 215 thousand tons in 2010 (FAO, 2012).

Increases in aquaculture productivity are influenced by increasing stocking density and subsequently increasing the amount of energy and materials used, such as fertilizers, allochthonous feed and aeration. However, this increase in productivity is also accompanied by an increase in the environmental impact caused by the release of effluents. The effluents from aquaculture tanks and ponds contain feces, unconsumed food, debris and plankton that may accelerate the eutrophication process; these effluents can also change communities of the receiving water bodies. For example, an increase of $400 \%$ in phytoplankton biomass and substantial dinoflagellates and chrysophyceae blooms were observed in lake regions close to a trout farm in Canada (Findlay et al., 2009). A recent study revealed that the floating aquatic macrophyte Salvinia molesta biomass (37.4 $\mathrm{g}$ dry matter $\mathrm{m}^{-2}$ ) was 12.5 times higher in a reservoir that received aquaculture effluent than the biomass $(3.0 \mathrm{~g}$ dry matter $\mathrm{m}^{-2}$ ) in the reservoir that was not impacted by the aquaculture activity (Pistori et al., 2010).

Treatment systems using aquatic macrophytes (constructed wetland) present a low cost and very efficient alternative to treating aquaculture effluents. The treatment of effluent from Oncorhynchus mykiss farming by the macrophyte Phragmites australis was able to reduce the concentration of total suspended solids by 95.8 to $97.3 \%$, total nitrogen concentration by 49 to $68.5 \%$ and total phosphorus concentration by 20.6 to $41.8 \%$ (Schulz et al., 2003). A constructed wetland colonized with the emergent macrophyte Spartina alterniflora used to treat the post-larvae effluent of the marine shrimp Litopenaeus vannamei reduced $\mathrm{NO}_{2}-\mathrm{N}(75 \%), \mathrm{NO}_{3}-\mathrm{N}(35$ to $55 \%)$ and P-orthophosphate concentration (59 to 64\%) (Sousa et al., 2011). In addition to reducing the concentration of nutrients and suspended solids, the advantages of constructed wetlands compared to conventional systems (sedimentation ponds or lagoons or aerobic and anaerobic reactors) are lower installation costs, low energy consumption, easy maintenance and operation (Solano et al., 2004). Other notable advantages of these systems include the flexibility regarding size, small area for installation and the possibility of controlling the residence time of the effluent in the wetland. In addition, the wetlands can also be built using different macrophytes species that can be appropriately arranged to increase system efficiency.

Floating aquatic macrophytes are used in constructed wetlands in several countries because of their high growth rate and great capacity to absorb and store nutrients (Costa-Pierce, 1998). Eichhornia crassipes, a free-floating macrophyte, has a great capacity to absorb and incorporate nutrients into its biomass, mainly in environments with high nitrogen and phosphorus concentrations (Henry-Silva and Camargo, 2006, 2008). S. molesta, another free-floating macrophyte, has a lower biomass than E. crassipes but also exhibits a high growth rate even in environments with lower nutrient availability (Camargo and Biudes, 2006). In natural environments, $S$. molesta occurs predominantly in aquatic systems with low $\mathrm{N}$ and $\mathrm{P}$ concentrations, while Pistia stratiotes occurs in rivers with higher concentrations of these nutrients (Camargo and Biudes, 2006). In a competition experiment comparing $P$. stratiotes and $S$. molesta, the latter presented greater biomass gain in nutrient-poor water, particularly in phosphorus absorption (Benassi and Camargo, 2000). Based on this information, this study aimed to test effluent treatment by a joint system consisting of two macrophytes arranged in series: E. crassipes in the first half of the wetland and S. molesta in the second half. Thus, we expect that the right placement of plants with different nutritional requirements would increase constructed wetland efficiency, with E. crassipes populating the more nutrient-rich half (effluent input in the wetland), and S. molesta populating the more nutrientpoor half (wetland outlet). Accordingly, we hypothesized that this macrophyte series arrangement is more efficient in treating aquaculture effluent than wetlands with one species alone.

\section{Material and Methods}

The experimental design was completely randomized with three treatments (wetlands with E. crassipes and $S$. molesta-EcSm; wetlands with only E. crassipes - Ec; and wetlands with only $S$. molesta $-\mathrm{Sm}$ ) consisting of three replicates each. The schematic of the experimental design is shown in Figure 1. The treatments were performed in nine rectangular fiberglass tanks with capacity of $1.6 \mathrm{~m}^{3}$ $(1.0 \times 0.8 \times 2.0 \mathrm{~m}$ width, height and length, respectively $)$ and were placed outdoors (Jaboticabal SP/Brazil 21 ${ }^{\circ} 15^{\prime} 22^{\prime}$ 'S and $48^{\circ} 18^{\prime} 48^{\prime \prime} \mathrm{W}$ ). The climate, according to Köppen, is defined as tropical rainy with dry winters and an average temperature in the coldest month of approximately $18^{\circ} \mathrm{C}$. The rainfall during the experimental period varied between $45.6 \mathrm{~mm}$ in March and $21.7 \mathrm{~mm}$ in May. The average highest and lowest temperatures during the period were $33.8^{\circ} \mathrm{C}$ and $16.5^{\circ} \mathrm{C}$, respectively.

The macrophytes used in the experiments were collected from stream-preserved ecosystems $\left(23^{\circ} 50^{\prime}-24^{\circ} 15^{\prime} \mathrm{S}\right.$ and $46^{\circ} 35^{\prime}-47^{\circ} 00^{\prime} \mathrm{W}$ ) where E. crassipes and S. molesta occur naturally and abundantly (Cancian et al., 2009). The macrophyte biomass was homogeneously distributed to cover approximately $80 \%$ of the tanks surfaces. The initial density used in the wetlands colonized by an individual species was $12.8 \mathrm{~kg}$ fresh mass $\mathrm{m}^{-2}(0.692 \mathrm{~kg}$ dry mass $\left.\mathrm{m}^{-2}\right)$ for E. crassipes and $3.7 \mathrm{~kg}$ fresh mass $\mathrm{m}^{-2}(0.180 \mathrm{~kg}$ dry mass $\mathrm{m}^{-2}$ ) for $S$. molesta. In the wetland colonized by both macrophytes, E. crassipes density was $8.5 \mathrm{~kg}$ fresh mass $\mathrm{m}^{-2}\left(0.461 \mathrm{~kg}\right.$ dry mass $\left.\mathrm{m}^{-2}\right)$ and $4.2 \mathrm{~kg}$ fresh mass $\mathrm{m}^{-2}\left(0.203 \mathrm{~kg}\right.$ dry mass $\left.\mathrm{m}^{-2}\right)$ for $S$. molesta.

The experiment was conducted with effluent received from a pond with a surface area of $193 \mathrm{~m}^{2}$ and an average depth of $1.1 \mathrm{~m}\left(212.3 \mathrm{~m}^{3}\right)$ used to maintain Macrobrachium rosenbergii broodstock. The effluent was driven by gravity 


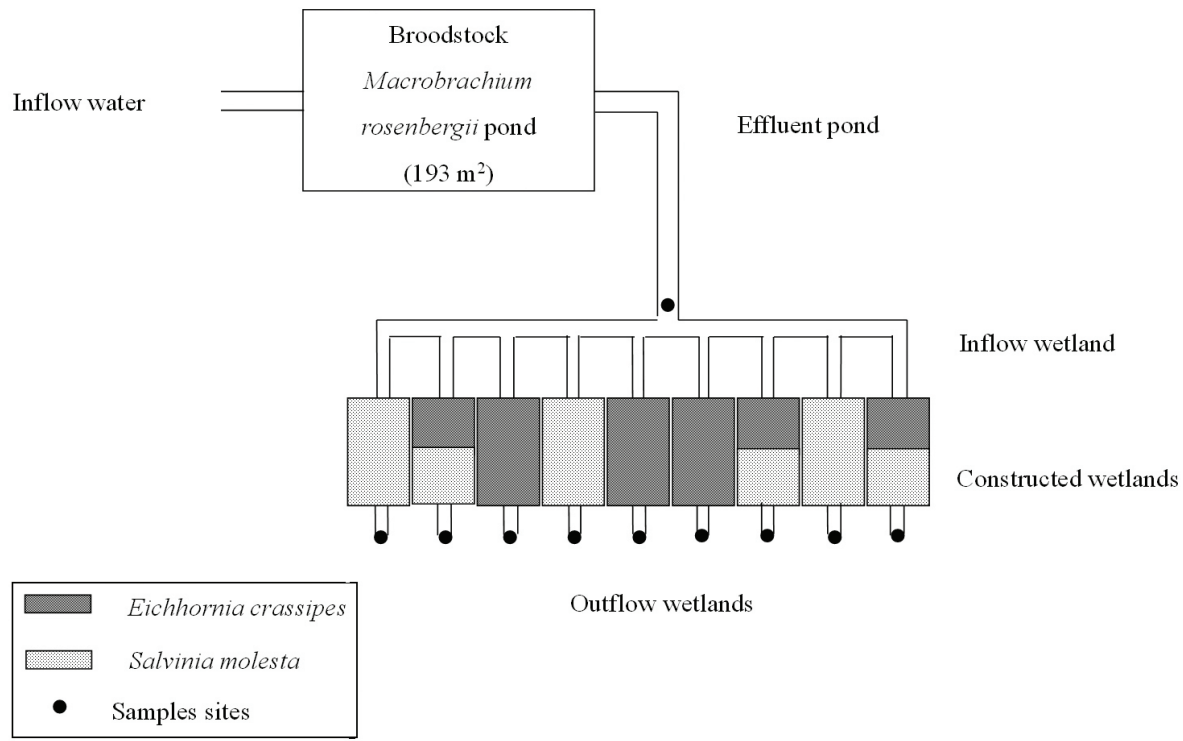

Figure 1. Schematic diagram of the effluent treatment from a Macrobrachium rosenbergii pond.

until wetlands. The water flow rate in wetlands each was regulated to 2.0-2.2 $\mathrm{L} \mathrm{min}^{-1}$ and was controlled and adjusted by flow rate meters installed at the tank inlet; the residence time was approximately 12 hours.

Pond management was performed according to the method traditionally used for $M$. rosenbergii broodstock (Daniels et al., 2000). Average stocking density during the experiment was $475.5 \mathrm{~g} \mathrm{~m}^{-2}$.

The experiment lasted 50 days (from March to April, 2007). Samples of one liter of effluent $(n=3)$ at the wetland inlet (influent - INF) were collected weekly, between 06:30 and 10:00 h. The following variables were determined from the samples in situ using a multiprobe (YSI model $556 \mathrm{MPS})$ : temperature $\left({ }^{\circ} \mathrm{C}\right)$, electrical conductivity $(\mathrm{mS}$ $\left.\mathrm{cm}^{-1}\right), \mathrm{pH}$ and dissolved oxygen concentration $\left(\mathrm{mg} \mathrm{L}^{-1}\right)$. Later in the day, between 18:00 and 22:00 h, the same variables were determined for the treated effluent.

Next, effluent samples were taken to the laboratory to determine other variables. Approximately $0.5 \mathrm{~L}$ of water was filtered on Whatman GF 52-C to determine suspended particulate material (SPM) (APHA, 2005) and the concentrations of ammonia nitrogen $\left(\mathrm{NH}_{3}-\mathrm{N}\right)$ (Koroleff, 1976), nitrite $\left(\mathrm{NO}_{2}-\mathrm{N}\right)$, nitrate $\left(\mathrm{NO}_{3}-\mathrm{N}\right)$ (Mackereth et al., $1978)$ and orthophosphate $\left(\mathrm{PO}_{4}-\mathrm{P}\right)$ (Golterman et al., 1978). The concentration of total inorganic nitrogen (TIN) was given by the sum of the inorganic nitrogen forms $\left(\mathrm{NH}_{3}-\mathrm{N}\right.$, $\mathrm{NO}_{2}-\mathrm{N}$ and $\left.\mathrm{NO}_{3}-\mathrm{N}\right)$. The non-filtered samples were used to determine total Kjeldahl nitrogen (TKN) (Mackereth et al., 1978) and total phosphorus (TP) (Golterman et al., 1978).

The efficiency of the wetlands was determined by the percent reduction of SPM, nitrogen and phosphorus concentration, according to the Equation 1:

$\mathrm{R}(\%)=100-\left[\left(100 * \mathrm{C}_{\mathrm{ET}}\right) / \mathrm{C}_{\mathrm{INF}}\right]$

where $\mathrm{R}(\%)=$ percent reduction; $\mathrm{C}_{\mathrm{ET}}\left(\mathrm{mg} \mathrm{L}^{-1}\right.$ or $\left.\mu \mathrm{g} \mathrm{L}^{-1}\right)=$ SPM, N and P concentrations in the treated effluent; and
$\mathrm{C}_{\mathrm{INF}}\left(\mathrm{mg} \mathrm{L}^{-1}\right.$ or $\left.\mu \mathrm{g} \mathrm{L}^{-1}\right)=\mathrm{SPM}, \mathrm{N}$ and $\mathrm{P}$ concentrations in the influent.

At the beginning and end of experiment, a quadrat with $0.25 \mathrm{~m}^{2}$ of $E$. crassipes and $S$. molesta was collected at the inlet and outlet of each tank. These samples were oven-dried at $60^{\circ} \mathrm{C}$ until constant weight to determine dry matter $\left(\mathrm{g} \mathrm{DM} \mathrm{m}^{-2}\right)$. Subsequently, the plants were ground to determine total nitrogen (TN \% DM) by the Kjeldahl method and total phosphorus (TP \% DM) (Allen et al., 1974).

The stock of nitrogen and phosphorus ( $\mathrm{g}$ of $\mathrm{N}$ or $\mathrm{P}$ ) in the macrophyte biomass was calculated as follows (Equation 2):

$\mathrm{S}=\mathrm{M} * \mathrm{C} / 100$

where $\mathrm{S}=$ stock $\left(\mathrm{g}\right.$ of $\mathrm{N}$ or $\left.\mathrm{P} \mathrm{m}^{2}\right) ; \mathrm{M}=$ dry matter $(\mathrm{g})$ and $\mathrm{C}=$ concentration $(\% \mathrm{DM})$.

Nitrogen and phosphorus accumulated in the macrophyte biomass was determined by the difference between the final and initial amount.

Normal distribution of the values of water and $\mathrm{N}$ and $\mathrm{P}$ accumulated in the macrophytes biomass was confirmed by Kolmogorov-Smirnov test; Barllett's test was conducted to examine the homogeneity of variances. We used ANOVA with repeated measures to verify the effects of wetland type (EcSm, Ec and $\mathrm{Sm})$ on the limnological variables and used one-way ANOVA to verify differences between $\mathrm{N}$ and $\mathrm{P}$ stocks on macrophytes biomass. Significantly different means were compared by Tukey's test $(P<0.05)$.

\section{Results}

The average temperature of the influent $\left(27.3 \pm 2.0^{\circ} \mathrm{C}\right)$ was higher than the $\mathrm{EcSm}\left(26.4 \pm 2.9^{\circ} \mathrm{C}\right), \mathrm{Ec}\left(25.5 \pm 2.9^{\circ} \mathrm{C}\right)$ and $\mathrm{Sm}\left(26.6 \pm 2.6^{\circ} \mathrm{C}\right)$ wetlands. The mean $\mathrm{pH}$ values were 6.9 and 7.3 in the EcSm and Sm wetlands, respectively, and ranged between 7.8 to 8.9 in the influent. The mean 
electrical conductivity was also higher in the influent $\left(0.100 \pm 0.02 \mathrm{mS} \mathrm{cm}^{-1}\right)$ than in the EcSm and Sm wetlands $\left(0.089 \pm 0.01 \mathrm{mS} \mathrm{cm}^{-1}\right)$ and the Ec wetland $\left(0.086 \pm 0.01 \mathrm{mS} \mathrm{cm}^{-1}\right)$.

The repeated measures ANOVA pointed to significant effects of treatments (wetlands type) and time (samplings periods) upon all variables. Interactions among the effects of time and wetlands were also observed for all variables (Table 1).

The effluent treated in the wetlands colonized with E. crassipes (Ec and EcSm) had lower levels of SPM. In the Ec wetland, SPM concentration was significantly $(P<0.05)$ lower than in the EcSm and Sm wetlands (Table 1). SPM decreased an average of $47.0 \%$ and $27.0 \%$ in the Ec and EcSm wetlands, respectively. In the Sm wetland, SPM increased by $8.7 \%$ (Table 1). The mean dissolved oxygen concentration (DO) was higher in the influent compared to all wetlands. DO concentration was significantly $(P<0.05)$ higher in the Sm wetland than in the EcSm and Ec wetlands. The DO levels decreased $31.1 \%, 51.3 \%$ and $70.8 \%$ in the $\mathrm{Sm}, \mathrm{EcSm}$ and Ec wetlands, respectively, compared to the influent (Table 1).

The wetland colonized with E. crassipes only was more efficient in reducing nitrogen and phosphorus, as TIN, TKN, $\mathrm{PO}_{4}-\mathrm{P}$ and TP concentrations were significantly $(P<0.05)$ lower in the Ec wetland (Table 1). The Ec wetland reduced TIN, TKN, $\mathrm{PO}_{4}-\mathrm{P}$ and $\mathrm{TP}$ concentration by $46.0,43.3,44.5$ and $43.6 \%$, respectively. In the EcSm wetland, the reduction of TIN (23.0\%), TKN (34.3\%) and $\mathrm{PO}_{4}-\mathrm{P}(26.7 \%)$ was similar to the TIN, TKN and $\mathrm{PO}_{4}-\mathrm{P}$ reduction in the Sm wetland (19.8\%, 31.3\% and 23.8\%, respectively). Among the EcSm and Sm wetlands, TP reduction was higher in the system colonized with both macrophytes $(24.1 \%)$ compared to the system colonized with $S$. molesta only (14.3\%) (Table 1$)$.

The SPM concentration was higher in the treated effluents (Sm, Ec and EcSm) compared to the influent at the beginning of the experiment. After 15 days, SPM was lower in the Ec and EcSm wetlands than in the influent. Beginning from the $29^{\text {th }}$ day, the SPM concentration in the Ec wetland was significantly $(P<0.05)$ lower compared to the concentration in the Sm wetland (Figure 2A). DO concentrations in the wetlands presented similar behavior throughout the experiment, but were significantly higher $(P<0.05)$ in the Sm wetland (Figure 2B).

The TIN concentrations at the beginning of the experiment were higher in the Sm wetland. The TIN concentrations decreased in the three wetlands during the experiment; however, in most of the samples the TIN concentrations were significantly $(P<0.05)$ lower in the Ec wetland (Figure 2C). Starting from the $29^{\text {th }}$ day of the experiment, the TKN concentrations were also significantly $(P<0.05)$ lower in the Ec wetland (Figure 2D). The $\mathrm{PO}_{4}$-P and TP concentrations were significantly $(P<0.05)$ lower in the Ec wetland; this wetland also had the lowest concentrations of $\mathrm{PO}_{4}-\mathrm{P}$ starting at the $29^{\text {th }}$ day of the experiment and lower TP concentrations starting at the $15^{\text {th }}$ day (Figures 2E, F).

At the beginning of the experiment, the mean amount of nitrogen in the E. crassipes and $S$. molesta biomass was $9.9 \pm 2.7$ and $3.5 \pm 0.2 \mathrm{~g} \mathrm{~m}^{2}$, respectively. The initial amount of phosphorus was $3.2 \pm 0.8$ and $0.57 \pm 0.05 \mathrm{~g} \mathrm{~m}^{2}$ in the E. crassipes and $S$. molesta biomass, respectively. The $\mathrm{N}$ and $\mathrm{P}$ stock was significantly $(P<0.05)$ higher in the $E$. crassipes biomass than the $S$. molesta biomass. In the Ec wetland, $\mathrm{N}$ and $\mathrm{P}$ stock in the macrophytes were 2.1 and 2.3 times higher, respectively, compared to the stock in the biomass of the EcSm wetland (Table 2). The $\mathrm{N}$ and $\mathrm{P}$ stock in the macrophytes from the Ec wetland was 5.1 and 3.2 times higher, respectively, compared to the biomass of the Sm wetland (Table 2). Among EcSm and $\mathrm{Sm}$, the highest $\mathrm{N}$ stock was observed in the biomass from the EcSm wetland. No significant difference $(P<0.05)$ was observed among EcSm and Sm wetlands for P stock (Table 2).

\section{Discussion}

The objective of this study was to verify if wetlands arranged in series by plants with different nutritional requirements would be more efficient in treating aquaculture effluent than wetlands colonized by a single species alone. The results of this experiment do not support our hypothesis that a series arrangement with E. crassipes and $S$. molesta is more efficient in improving the quality of effluent. Overall, the three constructed wetlands were able to reduce

Table 1. Means $(n=24)( \pm$ standard deviation $)$ of limnological variables in the influent wetland (INF) and treated effluent in the EcSm, Ec and Sm wetlands with results from the repeated measures ANOVA $(P)$ upon the effects of treatment time and wetland type.

\begin{tabular}{|c|c|c|c|c|c|c|c|}
\hline \multirow{2}{*}{$\begin{array}{l}\text { Limnological } \\
\text { variables }\end{array}$} & \multirow{2}{*}{ INF } & \multirow{2}{*}{ EcSm } & \multirow{2}{*}{ Ec } & \multirow{2}{*}{ Sm } & \multicolumn{3}{|c|}{ ANOVA $P$ value } \\
\hline & & & & & Wetland & Time & Interaction \\
\hline SPM $\left(\mathrm{mg} \mathrm{L}^{-1}\right)$ & $21.8 \pm 10.6$ & $16.0 \pm 8.9$ & $12.0 \pm 11.7$ & $23.7 \pm 12.1$ & 0.009 & $<0.001$ & $<0.001$ \\
\hline $\mathrm{DO}\left(\mathrm{mg} \mathrm{L}^{-1}\right)$ & $6.2 \pm 0.6$ & $3.0 \pm 0.7$ & $1.8 \pm 0.7$ & $4.3 \pm 0.97$ & $<0.001$ & $<0.001$ & $<0.001$ \\
\hline $\operatorname{TIN}\left(\mu \mathrm{g} \mathrm{L}^{-1}\right)$ & $171.6 \pm 52.7$ & $132.1 \pm 38.6$ & $92.6 \pm 21.7$ & $137.6 \pm 63.4$ & $<0.001$ & $<0.001$ & $<0.001$ \\
\hline TKN $\left(\mathrm{mg} \mathrm{L}^{-1}\right)$ & $0.67 \pm 0.11$ & $0.44 \pm 0.10$ & $0.38 \pm 0.09$ & $0.46 \pm 0.08$ & $<0.001$ & $<0.001$ & $<0.001$ \\
\hline $\mathrm{PO}_{4}-\mathrm{P}\left(\mu \mathrm{g} \mathrm{L}^{-1}\right)$ & $65.2 \pm 17.0$ & $47.8 \pm 20.5$ & $36.2 \pm 15.5$ & $49.7 \pm 23.9$ & $<0.001$ & $<0.001$ & $<0.001$ \\
\hline $\mathrm{TP}\left(\mu \mathrm{g} \mathrm{L}^{-1}\right)$ & $234.7 \pm 32.0$ & $178.2 \pm 49.7$ & $132.3 \pm 41.9$ & $201.2 \pm 25.6$ & $<0.001$ & $<0.001$ & $<0.001$ \\
\hline
\end{tabular}

$\mathrm{SPM}=$ suspended particulate matter; $\mathrm{DO}=$ dissolved oxygen; $\mathrm{TIN}=$ total inorganic nitrogen; $\mathrm{TKN}=$ total Kjeldahl nitrogen; $\mathrm{PO}_{4}-\mathrm{P}=\mathrm{P}$-orthophosphate; $\mathrm{TP}=$ total phosphorus. 
the amount of SPM and different forms of nitrogen and phosphorous concentrations. However, we observed that these wetlands presented different reduction efficiencies.

The reduction of SPM and particulate nitrogen and phosphorous in constructed wetlands is due to sedimentation and retention in the roots of free-floating aquatic macrophytes.
The sedimentation process is favored by the shallowness of the wetland system and the residence time of the influent in the wetland. Longer residence time favors sedimentation of suspended solids and results in treated effluent containing lower levels of SPM and particulate N and P. The wetland colonized only by $E$. crassipes more effectively reduced
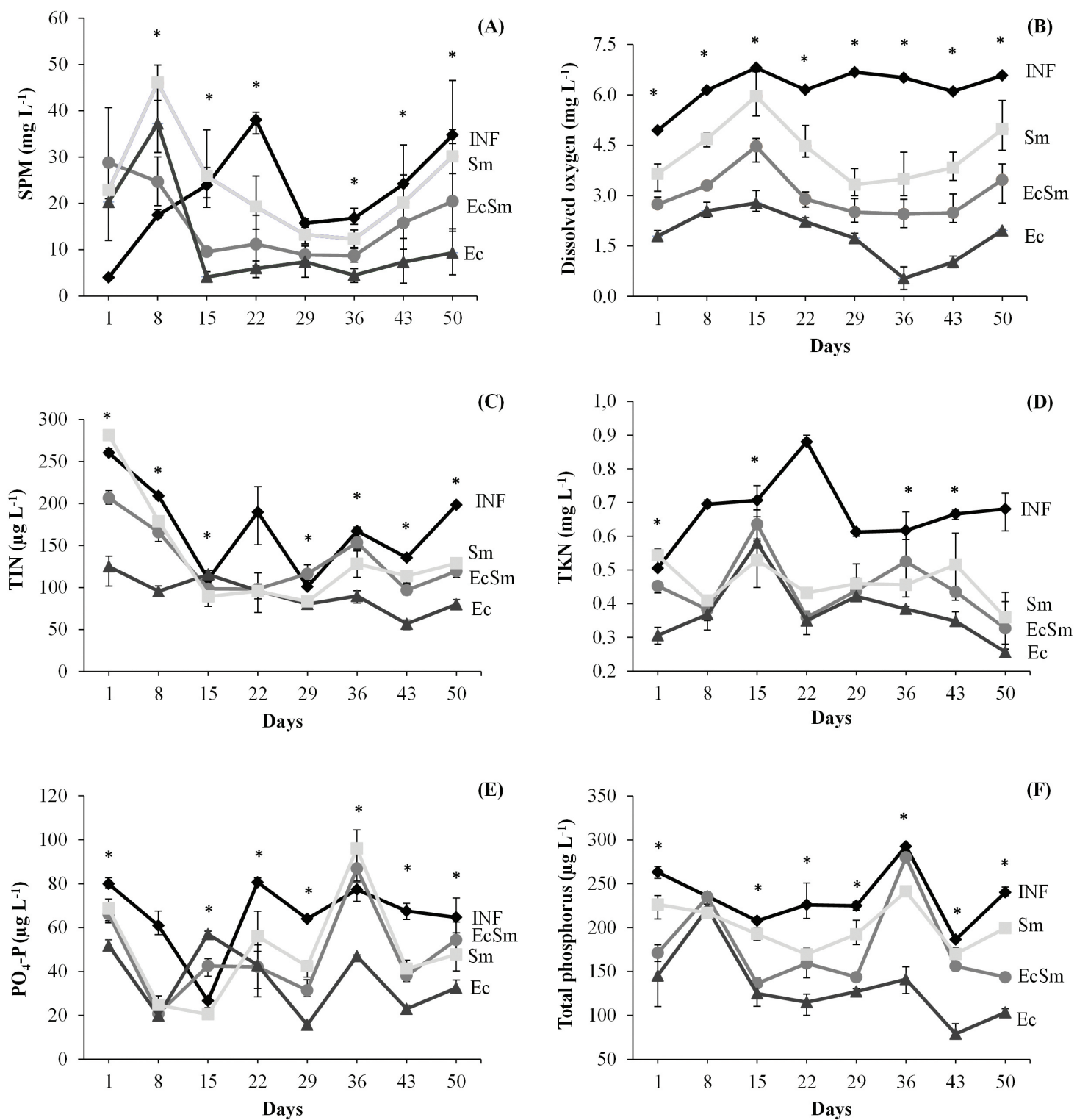

Figure 2. Means $(n=3)$ and standard deviations of limnological variables of the influent (INF) and effluent treated in the wetlands $(\mathrm{EcSm}, \mathrm{Ec}$ and $\mathrm{Sm})$. *denotes significantly different $(P<0.05)$ between treatments.

Table 2. Means $(n=3)( \pm$ standard deviation) of nitrogen $(N)$ and phosphorus $(P)$ stocks in the biomass of aquatic macrophytes in each wetland system.

\begin{tabular}{crrrr} 
& \multicolumn{3}{c}{ Stocks of N e P } & \multirow{2}{*}{ ANOVA $P$ value } \\
\cline { 2 - 4 } & EcSm & Ec & Sm & \\
\hline $\mathrm{N}(\mathrm{g})$ & $14.7 \pm 3.0(\mathrm{~b})$ & $30.3 \pm 2.7(\mathrm{a})$ & $5.9 \pm 2.8(\mathrm{c})$ & $<0.001$ \\
$\mathrm{P}(\mathrm{g})$ & $2.4 \pm 0.4(\mathrm{~b})$ & $5.5 \pm 1.4(\mathrm{a})$ & $1.72 \pm 0.7(\mathrm{~b})$ & 0.005 \\
\hline
\end{tabular}

Different letters mean significant differences among the constructed wetlands. Means followed by different letters are significantly different $(P<0.05)$ by Tukey's test. 
the SPM and nutrient concentrations of the effluent from the $M$. rosenbergii broodstock pond than others wetlands. Its roots system may have influenced the efficiency of the wetland, as E. crassipes root structure is larger compared to Salvinia (Meerhoff et al., 2003) and can favor retention and adsorption of dissolved and particulate matter, mainly unconsumed food and debris of dead animals that are carried from the pond. The root length of S. molesta varies from 23.9 to $104.7 \mathrm{~mm}$ (Room, 1983) and for E. crassipes the root length may reach 3,000 $\mathrm{mm}$ (Meerhoff et al., 2003). This extensive root length is likely one reason why SPM, nitrogen and phosphorus were efficiently reduced in the wetlands colonized with E. crassipes (Ec and EcSm wetlands).

In fact, the concentration of SPM in the Ec wetland was approximately 2 times lower than the concentration in the $\mathrm{Sm}$ wetland. One direct relationship between dry mass of roots and retained particulate matter for E. crassipes was observed by Poi de Neiff et al. (1994) in the Paraná River floodplain (Argentina). In addition to retention of solids, the roots favor sedimentation of particulate matter because it reduces the turbulence caused by the constant effluent inflow in the wetland.

In addition to sedimentation, the reduction of nitrogen and phosphorous in wetlands is related to the capacity of the macrophytes to absorb and store these nutrients in the vegetal biomass and to the adsorption debris, clays, organic compounds and carbonates. In general, aquatic macrophytes with higher biomass are more efficient in absorbing nutrients, as they exhibit a high capacity to absorb and store nutrients in their biomass (Gopal, 1990; Henry-Silva and Camargo, 2006). The reduction of $\mathrm{N}$ and $\mathrm{P}$ concentrations in an enriched environment with these nutrients by $E$. crassipes was higher than by S. auriculata (Petrucio and Esteves, 2000). The results reported by these authors may be related to the larger root surface of E. crassipes because this plant absorbs nutrients from the water column, predominantly through the roots (Tundisi and Tundisi, 2008). For floating aquatic macrophytes, the main nutrient source is from the water column (Trindade et al., 2011). The absorption of $\mathrm{N}$ and $\mathrm{P}$ by the epiphytic community adhered to the higher root surface of $E$. crassipes may have favored reduction of $\mathrm{N}$ and $\mathrm{P}$ in the wetlands.

The capacity of E. crassipes to absorb and stock more nutrients explains the greater efficiency in reduction of $\mathrm{N}$ and $\mathrm{P}$ by the Ec wetland compared to EcSm and Sm wetlands. The greater capacity to absorb nutrients resulted in higher $\mathrm{N}$ and $\mathrm{P}$ stock in the E . crassipes biomass in the Ec wetland than the $S$. molesta biomass in the $\mathrm{Sm}$ wetland. The E. crassipes final biomass in the Ec wetland was 4.6 times higher $\left(1,171.3 \mathrm{~g} \mathrm{DM} \mathrm{m}^{-2}\right)$ than the $S$. molesta in the Sm wetland $\left(255.0 \mathrm{~g} \mathrm{DM} \mathrm{m}^{-2}\right)$. In the EcSm wetland, E. crassipes final biomass was 2.2 times higher $\left(672.0 \mathrm{~g} \mathrm{DM} \mathrm{m}^{-2}\right)$ than the $S$. molesta biomass (301.8 $\mathrm{g} \mathrm{DM} \mathrm{m}^{-2}$ ). Therefore, there is a relationship between wetland efficiency, the macrophyte biomass and the capacity of the macrophyte to absorb and store $\mathrm{N}$ and $\mathrm{P}$.
The efficiency of nutrient removal by wetlands colonized by three different free-floating aquatic macrophytes was investigated by Henry-Silva and Camargo (2006). These authors verify that $E$. crassipes had a higher final biomass $\left(1,738.9 \mathrm{~g} \mathrm{DM} \mathrm{m}^{-2}\right)$ than $S$. molesta $\left(424.8 \mathrm{~g} \mathrm{DM} \mathrm{m}^{-2}\right)$ and removed more nitrogen and phosphorus from the effluents.

The concentrations of nutrients in the second half (final part) of the wetland likely were also high, which favored $E$. crassipes growth. If greater than $2 \mathrm{~m}$, a wetland with the same flow rate colonized with $E$. crassipes and $S$. molesta arranged in a series may be more efficient, because $E$. crassipes could more efficiently utilize the high $\mathrm{N}$ and $\mathrm{P}$ concentrations in the first half of the tank, whereas $S$. molesta could more adequately utilize the lower concentrations of these nutrients in the second half. In conclusion, the wetland with the greatest efficiency was colonized with E. crassipes only; this efficiency is likely related to the extensive roots and biomass of the plant and the small dimensions of the wetland. Therefore, in the smaller wetland colonized with floating aquatic macrophytes should be used plants with high aerial biomass and more importantly high root surface because these biological characteristics, particularly high root surface, favor shading and the formation of an extensive area suited to retain and adsorb debris and absorb nutrients.

\section{Acknowledgments}

The authors are grateful to Conselho Nacional de Desenvolvimento Científico e Tecnológico (CNPq) for providing fellowships for the first author. We would also like to thank the staff of the Crustacean Sector, CAUNESP, for technical support.

\section{References}

ALLEN, SE., GRIMSHAW, HM., PARKINSON, JA. and QUARMBY, C., 1974. Chemical analysis of ecological materials. Oxford: Blackwell Scientific. 565 p.

American Public Health Association - APHA, 2005. Standard methods for the examination of water and wastewater. 20th ed. Washington: American Water Works Association/Water Environment Federation.

BENASSI, RF. and CAMARGO, AFM., 2000. Avaliação do processo competitivo entre duas espécies de macrófitas aquáticas flutuantes, Pistia stratiotes e Salvinia molesta. Revista de Iniciação Cientifica, vol. 1, p. 59-66.

CAMARGO, AFM. and BIUDES, JFV., 2006. Influence of limnological characteristics of water in the occurrence of Salvinia molesta and Pistia stratiotes in rivers from the Itanhaém River basin (SP, Brazil). Acta Limnologica Brasiliensia, vol. 18, no. 3, p. 239-246.

CANCIAN, LF., CAMARGO, AFM. and SILVA, GHG., 2009. Crescimento de Pistia stratiotes em diferentes condições de temperatura e fotoperíodo. Acta Botanica Brasílica, vol. 23, no. 2, p. 552-557. http://dx.doi.org/10.1590/S0102-33062009000200027.

COSTA-PIERCE, BA., 1998. Preliminary investigation of an integrated aquaculture-wetland ecosystem using tertiary-treated 
municipal wastewater in Los Angeles County, California. Ecological Engineering, vol. 10, no. 4, p. 341-354. http://dx.doi.org/10.1016/ S0925-8574(98)00003-2.

DANIELS, WH., CAVALLI, RO. and SMULLEN, RP., 2000. Broodstock Management. In NEW, MB. and VALENTI, WC. (Eds.). Freshwater prawn culture: The farmimg of Macrobrachium rosenbergii. Oxford: Blackwell Science. p. 41-54. http://dx.doi. org/10.1002/9780470999554.ch4.

$<$ report $>$ Food and Agriculture Organization of United Nations FAO, 2012. Fisheries and Aquaculture Information and Statistics Service. Rome: FAO. $<$ /report $>$

FINDLAY, DL., PODEMSKI, CL. and KASIAN, SEM., 2009. Aquaculture impacts on the algal and bacterial communities in small boreal forest lake. Canadian Journal of Fisheries and Aquatic Sciences, vol. 66, no. 11, p. 1936-1948. http://dx.doi. org/10.1139/F09-121.

GOLTERMAN, HL., CLYNO, RS. and OHSNTAD, MAM., 1978. Methods for physical and chemical analysis of freshwater. 2nd ed. Oxford: Blackwell Science.

GOPAL, B., 1990. Aquatic weed problems and management in Asia. In PIETERSE, AH. and MURPHY, KJ. (Eds.). Aquatic weeds: The ecology and management of nuisance aquatic vegetation. Oxford: Oxford University Press. p. 318-340.

HENRY-SILVA, GG. and CAMARGO, AFM., 2006. Efficiency of aquatic macrophyte to treat Nile tilapia pond effluents. Scientia Agricola, vol. 63, no. 5, p. 433-438. http://dx.doi.org/10.1590/ S0103-90162006000500003.

HENRY-SILVA, GG. and CAMARGO, AFM., 2008. Tratamento de efluentes de carcinicultura por macrófitas aquáticas flutuantes. Revista Brasileira de Zootecnia, vol. 37, no. 2, p. 181-188. http:// dx.doi.org/10.1590/S1516-35982008000200002.

KOROLEFF, F., 1976. Determination of nutrients. In GRASSHOFF, K. (Ed.). Methods of seawater analysis. New York: Verlag. Chemie Weinhein. p. 117-181.

MACKERETH, FIF., HERON, J. and TALLING, JF., 1978. Water analysis: some revised methods for limnologist. London: Freshwater Biological Association. $121 \mathrm{p}$.

MEERHOFF, M., MAZZEO, N., MOSS, B. and RODRÍGUEZGALLEGO, L., 2003. The structuring role of free-floating versus submerged plants in a subtropical shallow lake. Aquatic
Ecology, vol. 37, no. 4, p. 377-391. http://dx.doi.org/10.1023/ B:AECO.0000007041.57843.0b.

PETRUCIO, MM. and ESTEVES, FA., 2000. Uptake rates of nitrogen and phosphorus in the water by Eichhornia crassipes and Salvinia auriculata. Revista Brasileira de Biologia, vol. 60, no. 2, p. 229-236. http://dx.doi.org/10.1590/S0034-71082000000200006. PMid:10959106

PISTORI, RET., HENRY-SILVA, GG., BIUDES, JFV. and CAMARGO, AFM., 2010. Influence of aquaculture effluents on the growth of Salvinia molesta. Acta Limnologica Brasiliensia, vol. 22 , no. 2 , p. 179-186

POI DE NEIFF, A., NEIFF, JJ., ORFEO, O. and CARIGNAN, R., 1994. Quantitative importance of particulate matter retention by the roots of Eichhornia crassipes in the Paraná floodplain. Aquatic Botany, vol. 47, no. 3-4, p. 213-223. http://dx.doi. org/10.1016/0304-3770(94)90054-X.

ROOM, PM., 1983. Falling apart as a lifestyle: the rhizome architecture and population growth of Salvinia molesta. Journal of Ecology, vol. 71, no. 2, p. 349-365. http://dx.doi. org/10.2307/2259719.

SCHULZ, C., GELBRECHT, J. and RENNERT, B., 2003. Treatment of rainbown trout farm effluents in constructed wetland with emergent plants and subsurface horizontal water flow. Aquaculture, vol. 217, no. 1-4, p. 207-221. http://dx.doi. org/10.1016/S0044-8486(02)00204-1.

SOLANO, ML., SORIANO, P. and CIRIA, MP., 2004. Constructed wetlands as sustainable solution for wastewater treatment in small village. Biosystems Engineering, vol. 87, no. 1, p. 109-118. http:// dx.doi.org/10.1016/j.biosystemseng.2003.10.005.

SOUSA, WTZ., PANITZ, CMN. and THOMAZ, SM., 2011. Performace of pilot-scale vertical flow constructed wetlands with and without the emergent macrophyte Spartina alterniflora treating mariculture effluent. Brazilian Archives of Biology and Technology, vol. 54, no. 2, p. 405-413. http://dx.doi.org/10.1590/ S1516-89132011000200024.

TRINDADE, CRT., ALBERTONI, EF. and PALMA-SILVA, C., 2011. Temporal variation in the biomass and nutriente status of Azolla filiculoides Lam. (SALVINIACEAE) in the small shallow dystrophic lake. Acta Limnologica Brasiliensia, vol. 23, no. 4, p. 368-375. http://dx.doi.org/10.1590/S2179-975X2012005000015.

TUNDISI, JG. and TUNDISI, TM., 2008. Limnologia. São Paulo: Oficina de Textos. $631 \mathrm{p}$. 